\title{
Are serial acquirers good targets for acquisition? An Accounting Perspective
}

\author{
Matthias Nnadi ${ }^{1}$ \\ School of Management, \\ Cranfield University, UK \\ Saliesh Tanna \\ School of Economics, Finance \& Accounting, \\ Coventry University, UK
}

\begin{abstract}
This study uses the positivist agency theory to examine if serial acquirers with consistently negative cumulative abnormal returns over their past acquisitions are more likely to become targets themselves. The study is based on the assumption that firms that make repeated value reducing acquisitions and depress their stock price are more attractive targets than firms that make good returns to their shareholders through acquisitions, and whose share prices increase correspondingly. Our findings show that serial acquirers that are considered bad bidders are more likely to become targets themselves compared to those that are considered good bidders. While this is the case in the United States and Europe, we find limited evidence to show that the same disciplinary tool is applicable in other parts of the world.
\end{abstract}

Keywords: disciplinary; bidders; takeover; acquisition; bad; serial; good; returns

\footnotetext{
${ }^{1}$ Corresponding email: Matthias.nnadi@cranfield.ac.uk
} 


\section{Introduction}

The direct consequence of principle-agency cost problem is that managers often engage in transactions that are value destroying, depressing the market value of the shares and diminishing the wealth of their equity holders, while they entrench their positions by getting to rule over a larger empire. The difference created by the gap between the actual (depressed) share price and the potential share price eventually becomes an incentive for an external party's intervention, seeing it as a rosy target to acquire, get rid it of its incompetent management and run it in a way that maximizes profits for the new shareholders (Chemla, 2005; Grinstein, 2006).

That value destroying acquisitions amounts to poor performance which increases the likelihood of the firm becoming a takeover target is well known in the takeover literature. (Mitchell and Lehn, 1990; Kini et al, 2004). This paper focuses on determining the extent to which managers are disciplined when there is a conflict between the acquisition strategy of management and that of shareholders' interest.

Our study leans on the positivist agency paradigm, and provides evidence that curbing agent opportunism and extremism in a ubiquitous agency relationship helps to align the preferences of the agent with those of the principal. The consequences of reckless actions by the agent, measured by value diminishing acquisitions, can trigger a takeover bid for the firm. The takeover threat therefore becomes both behavioural and outcome oriented which serves to reduce bad acquisitions and managerial opportunism (Eisenhardt, 1989). However, there is limited cross-country evidence that takeover as a control and corporate governance mechanism can effectively reduce the potential scope for serial acquisitions.

Empirical studies that use prior acquisition history as a measure of managerial performance suggest that value can be created by acquiring firms with poor acquisition programmes. For 
example, Mitchell and Lehn (1990) and Offenberg (2009) find that firms that destroy shareholders value through poor acquisitions are subsequently more likely to become takeover targets themselves. The worst acquisitions that are made by firms that are later divested either in bust-up takeovers or restructuring programmes to thwart takeovers. Lehn and Zhao (2006) show that CEOs who make value-reducing acquisitions are more likely than others to be replaced through internal and external control mechanisms, including takeovers.

The paper extends the approach of Mitchell and Lehn (1990) by incorporating broader sample. The current study uses 14,316 acquisitions which occurred across the globe between 2003 and 2013, these being classified as either hostile or friendly. The period of the study witnessed the most prolific global merger and acquisition activities and therefore provides a better insight on the contemporary use of targeted acquisition as a disciplinary tool. Most studies that have considered takeover as a disciplinary tool have often focused on individual countries (Mitchell and Lehn, 1990; Mikkelson and Partch, 1997; Scharfstein, 1988). The study combines both the behaviour-oriented and outcome-oriented agency theories and their implications in the use of takeover as a disciplinary tool across different countries.

The rest of the paper is organised as follows: section two provides the theoretical framework and a review of the literature on disciplinary measures and poor managerial performance. Section three describes the data used while section four discusses the development of the model and hypotheses. Sections five and six presents the descriptive and empirical results respectively, and section seven is the conclusion.

\section{Theoretical framework and review of literature}

Our study develops from the positivist agency theory which posits that when there is a conflict between the principal and the agent, and it is costly for the principal to observe or verify the actions of the agent, then curbing the agent's opportunism and extremism become 
inevitable (Eistenhardt, 1989). Mergers or acquisitions provide such tangential and ambivalent opportunity through which shareholders can wedge disciplinary measures on the management, particularly where past acquisitions have consistently failed or performed below expectations (Chemla, 2005; Grinstein, 2006).

Such disciplinary measures can be expended through behaviour-oriented contracts as well as outcome-oriented contracts, which subsist between the directors and shareholders of the firm. Although both are reward based, the former involves control over salaries and entitlements while the latter is based on commission payments associated with the outcome of transactions. The positivism theorist argue that both tools aim to make the managers feel jittery over acquisitions that are perceived as too risky for the business, as the consequences may be unpleasant (Pleffer, 1981; Jensen and Meckling, 1976). The penalty may be a revolution in the ownership and management of the firm. The other argument is that reward based contracts tend to deter managers from taking inevitable investment risks that may have potential benefits to the business.

Denis and Kruse (2000) outlined three major disciplinary measures which include, corporate takeovers, board dismissals, and shareholder activism which are, commonly used against poor performing management. Such corporate governance measures do not in themselves reduce low performance by management but rather spurs them to create better value for their shareholders. The reasoning behind the disciplinary takeover argument is that poor performance will prompt bidders to take over firms, which could lead to a loss for the stakeholders. Since the stakeholders anticipate this, the threat of a takeover provides them with incentives to insist on creative value and invest more funds (Chemla, 2005). This is based on the assumption that poor performance is usually associated with low stakeholders' investment which could prompt takeover bids, yielding negative consequences to the stakeholders.

Though some of the disciplinary techniques against poor performing management have remained questionable, their use as tools of discipline is unequivocal. Frank and Mayer (1996) note that high board turnover does not derive from past managerial failure and therefore argue that hostile takeovers cannot be used as a disciplining measure. Shivdasani (1993) examines a sample of takeover bids that are perceived to be disciplinary in nature and asserts that hostile takeovers provide discipline when internal governance mechanisms such as the board of directors fail to control management's non-value-maximizing behaviour. The operations and nature of corporate governance differ across countries. Therefore, the 
implications of these findings outside the US may not be same. For instance, cultural and legal differences between Europe, Africa and Asia may be key to understanding how board turnover and internal governance mechanisms work.

Disciplinary actions can also be in forms of managerial replacement or liquidation of the company. Grinstein (2006) and Weisbach (1993) argue that the potential replacement of managers through a hostile takeover provides incentives for them to take actions that keep their stock price as high as possible. In the US, one of such catalyst of disciplinary takeover is through shareholders class action which involves legal actions against managers of companies that are accused of poor disclosure, performance and issuing misleading statements to the market (Humphrey-Jenner, 2012).

Even among firms that are not taken over, corporate takeover activity can play a role in disciplining poor performing managers. Takeover and takeover-related activity assist corporate boards in carrying out their charge to oversee and discipline management. Mikkelson and Partch (1997) argue that takeover activity facilitates the replacement of managers of poor performing firms and argue that corporate managers face less pressure to maximize value when takeover activity diminishes.

\section{Description of data}

The sample used in this study is drawn from the SDC Platinum mergers and acquisitions database over a 10-year period from 2003 through 2013. This was a period of increased takeover activities across the globe. Daily data for the market return were collected from DataStream for each transaction based on the local index of the acquiring firms i.e. S\&P 500 for US acquirers, FTSE all share index UK acquirers, ISRAEL TA 100 price index for Israeli acquirers, etc. Any transactions where data are not available for the local index of the acquiring firm were dropped.

The sample comprises of 2,933 public companies drawn from three main geographical groups from around the world, which are: 
- United States of America (US): comprising all transactions where the bidding firm is incorporated in the United States of America. These consist of 1,274 firms (43\% of the total sample) that made a total of 6,835 transactions ( $48 \%$ of the total transactions made by the entire sample)

- Europe (Eur): comprising of all transactions where the bidding firm is incorporated in countries that are in Europe. They comprise 838 companies $(29 \%$ of the total sample) which between them carried out 4,165 M\&A transactions (amounting to 29\% of the total sample). It is noteworthy that of this figure, the UK accounts for 2,586 (62\% of the European sample transactions) transactions made by 456 corporations (54\% of the European serial acquirers). This is no surprising as the UK has the most developed stock market in Europe ${ }^{2}$, with very high disclosure requirements and protections for shareholders (Sudarsanam and Mahate, 2003).

- The Rest of the World (ROW): 821 firms (28\% of the sample acquirers) from all countries aside from those mentioned above fall into this category. Between them, they executed 3,316 transactions accounting for $23 \%$ of the total sample transactions.

To be included in the sample, the firms had to satisfy the under-listed criteria:

a. Be a public corporation listed in a national exchange in its country of origin between $1^{\text {st }}$ January 2003 and $30^{\text {th }}$ June 2013.

b. Have carried out at least 3 mergers or acquisitions between the $1^{\text {st }}$ of January, 2003 and $31^{\text {st }}$ December 2011.

c. The minimum deal value of the three transactions referred to in (b) above must be one million US dollars $(\$ 1,000,000)$ or its equivalent.

d. The bidder must own less than $50 \%$ of the target before the deal and more than $50 \%$ after the deal has been completed.

\footnotetext{
2 The London Stock Exchange was founded in 1801 and currently has a market capitalisation of about US\$3.433 trillion (August 22, 2013) making it the largest exchange in Europe and the fourth largest in the world.
} 
e. Have complete data in SDC Platinum and DataStream as summarised in Table 1.

The targets in the sample include public firms, private firms, subsidiaries or divisions in a corporation. Additionally,

- All transactions in the sample were completed deals which meant the exclusion of pending and withdrawn transactions.

- Minority stake purchases, share repurchases, leveraged buyouts, management buyouts and exchange offers are controlled for in the sample.

- The acquiring firm is required to own less than $50 \%$ of the target before the deal and more than $50 \%$ after the deal is concluded.

- The sample also excludes all firms in the highly regulated financial services industries for both acquirers and targets. 
Table 1: Summary statistics of acquisitions 2003 -2013

The table provides descriptive statistics of total sample used in the study. It also shows the total acquisitions, size of firms across US, Europe and the rest of the world.

\begin{tabular}{|c|c|c|c|c|c|c|c|c|c|c|}
\hline \multirow[t]{2}{*}{ Category } & \multirow{2}{*}{$\begin{array}{l}\text { Number } \\
\text { of firms }\end{array}$} & \multirow{2}{*}{$\begin{array}{c}\text { Number of } \\
\text { acquisitions }\end{array}$} & \multirow{2}{*}{$\begin{array}{l}\text { Average } \\
\text { size of } \\
\text { firms }\end{array}$} & \multirow{2}{*}{$\begin{array}{c}\text { Average } \\
\text { size of } \\
\text { targets }\end{array}$} & \multirow{2}{*}{$\begin{array}{l}\text { Average size } \\
\text { of } \\
\text { acquisitions }\end{array}$} & \multirow{2}{*}{$\begin{array}{c}\text { Median size } \\
\text { of } \\
\text { acquisitions }\end{array}$} & \multicolumn{4}{|c|}{ Form of financing } \\
\hline & & & & & & & All cash & All stock & $\begin{array}{c}\text { Cash \& } \\
\text { stock }\end{array}$ & Others \\
\hline $\begin{array}{l}\text { Total } \\
\text { sample }\end{array}$ & 2933 & 14316 & 4506 & 1560 & 0.35 & 0.04 & 6395 & 974 & 2034 & 4912 \\
\hline US & 1274 & 6835 & 5779 & 2241 & 0.39 & 0.04 & 3111 & 354 & 920 & 2331 \\
\hline EUR & 838 & 4165 & 3406 & 1678 & 0.49 & 0.05 & 1952 & 122 & 553 & 1588 \\
\hline ROW & 821 & 3316 & 3654 & 383 & 0.10 & 0.05 & 1332 & 498 & 561 & 993 \\
\hline
\end{tabular}

SOURCE: Own calculations based on data from SDC Platinum 
The samples are further classified into three main groups, as shown in Table 2, on the basis of whether the firm was a takeover target during the period January 2003 to June 2013:

- Non-targets: these companies had not received friendly or hostile bids and had neither paid greenmail nor were subjected to large unsolicited open-market purchases. This group consists of a total of 2,314 firms, representing $78.9 \%$ of the total sample size.

- Hostile Targets: this group consists of 67 firms that were targets of successful or unsuccessful hostile tenders and/or large unsolicited open-market purchases in which the purchaser had attempted to gain control of the company.

- Friendly targets: this group consists of 552 firms which were targets of tender offers, leveraged buy-outs, mergers etc., whether successful or not.

\section{Financial data}

As with the rest of the data, all financial data were obtained from DataStream. Previous studies have attempted to understand how the financial structure of a firm affects the probability that such a firm would become a target. Franks and Mayer (1996); Franks, Mayer and Renneboo (2001) show that less profitable firms are more likely to become targets hence, we include two variables - return on equity and leverage - in our model as control variables.

Others (Baker and Kennedy, 2002), have argued that high levels of leverage would make a firm an attractive target as the new owner would benefit a lot from the huge tax shield created by the leveraged firm, especially if the acquiring firm itself has a very low leverage level. 


\section{Bidder Quality}

The quality of each bidder is measured by cumulating abnormal returns (CAR) from all the acquisitions made by that firm over the observed period. The CAR which measures the total impact of a firm's acquisition activities on shareholder's wealth. This makes the total abnormal return the primary variable of interest. It indicates if a company has kept to its goal of shareholder's wealth maximization or whether it has gone in the opposite direction and thereby reduced the wealth of its shareholders through its acquisition activities.

The CAR solves some methodological challenges and reduces the risk of bias in the results. For instance, using an average would not indicate the total change in shareholders wealth, whilst using just one acquisition to judge the quality of a serial acquirer ignores much information about the quality of the company's other acquisitions which are very important.

Firms that have a negative total abnormal return are often labelled as bad bidders as the total impact of their acquisition activities have had a negative effect on shareholder's wealth. Conversely, firms with total abnormal return that is non-negative are classified are good bidders as their acquisition activities have either left shareholders the same or have increased the total wealth of the shareholders.

\section{Dummy variable}

A dummy variable (BBD) is included with its value set at 1 if the firm is considered a bad bidder and 0 if otherwise. 
Table 2: Summary statistics of acquisitions based on subsequent standing, 2003 -2013

The table shows the number of firms by their subsequent ownership standing, the number of acquisitions that were carried out during the period, a description of the relative mean and median of the acquisitions made, and the forms of payment used in the acquisition

\begin{tabular}{|c|c|c|c|c|c|c|c|c|}
\hline \multirow[t]{2}{*}{ Category } & \multirow{2}{*}{$\begin{array}{l}\text { Number } \\
\text { of firms }\end{array}$} & \multirow{2}{*}{$\begin{array}{l}\text { Number of } \\
\text { acquisitions }\end{array}$} & \multirow{2}{*}{$\begin{array}{c}\text { Average size } \\
\text { of } \\
\text { acquisitions }\end{array}$} & \multirow{2}{*}{$\begin{array}{l}\text { Median size } \\
\text { of } \\
\text { acquisitions }\end{array}$} & \multicolumn{4}{|c|}{ Form of financing } \\
\hline & & & & & $\begin{array}{l}\text { All } \\
\text { cash }\end{array}$ & $\begin{array}{c}\text { All } \\
\text { stock }\end{array}$ & $\begin{array}{c}\text { Cash } \\
\& \\
\text { stock }\end{array}$ & Others \\
\hline Total sample & 2933 & 14316 & 0.26 & 0.07 & 5542 & 4077 & 4833 & 2889 \\
\hline Non-Targets & 2314 & 11291 & 0.27 & 0.07 & 4672 & 2075 & 3031 & 1513 \\
\hline Hostile Targets & 67 & 312 & 0.21 & 0.09 & 86 & 73 & 76 & 77 \\
\hline Friendly Targets & 552 & 2713 & 0.18 & 0.09 & 349 & 928 & 825 & 611 \\
\hline
\end{tabular}

SOURCE: Own calculations based on data from SDC Platinum 


\section{Abnormal Returns}

The quality of each individual acquisitions attempt is measured by a cumulative abnormal return (CAR). Using the market model, the abnormal returns are estimated in a window of 2/+2 as:

$$
A R_{i t}=R_{i t}-\hat{R}_{i t}=R_{i t}-\hat{\alpha}_{i}-\hat{\beta}_{i} R_{m t}
$$

Where: $A R_{i t}$ is the abnormal return for company $\mathrm{i}$

$R_{i t}$ is the observed stock return in day $\mathrm{t}$

$\hat{R}_{i t}$ is the estimated normal return in day $\mathrm{t}$

$t$ is the day relative to the event day 0

$\hat{\alpha}_{i}+\hat{\beta}_{i} R_{m t}$ denotes the normal return of the company due to te market-wide movement.

To ensure that the results obtained in thus study are robust, four event windows are used throughout and compared. The introduction of three more windows would ensure that the analysis is done in short, medium and relatively long-term windows. This would simultaneously reduce the bias of short term studies and provide confirmation that the results obtained would still be obtained should the event windows be changed.

The abnormal returns are also calculated just on the announcement day $\{0\}$, five days before to five days after the announcement date $\{-5,5\}$, and ten days before to five days after the event day $\{-10,5\}$. For all event windows, the estimation window remains the same, beginning 60 days before the event and ending 30 days before the event $\{-60,-30\}$. The event 
date for each acquisition is set to the date that that the deal is announced by either of the companies involved, as captured on SDC platinum.

\section{Firm Size}

Gorton et al (2009) proposed that firms avoid takeover by increasing their size through acquisitions. Hence, the market value of each firm at the end of the year following the acquisition is used as a proxy for the size of the acquiring company. This way, the increase in the size of each firm by its last acquisition is captured in the size of the firm. Past studies (Palepu, 1986; Gorton et al, 2009; and Choi et al, 2001) show that bidder quality has an inverse relationship with size. Hence, as the size decreases, bidder quality should increase ceteris paribus. In most previous studies, the proxy for size is the natural logarithm of inflation-adjusted sales or even the actual sales rather than the market capitalisation (Humphery-Jenner, 2012).

\section{Development of model and hypotheses}

We used the Logit model to estimate the probability that a bad bidder could become a target. The dependent variable is set to 1 if the firm subsequently becomes a target and 0 if otherwise. While the key explanatory variable is the cumulative abnormal returns, there is much interest in observing the effects that size, profitability and leverage of the serial acquirers have on the probability of being a subsequent target.

If the market for corporate control functions as expected in disciplining bad bidders, firms with negative total abnormal returns will more likely be targeted while firm with positive cumulative abnormal returns would less likely be targeted. It is thus expected that if the coefficient of CAR is negative and significant, the effectiveness of the disciplinary 
mechanism of the market would be substantiated. But if the coefficient turns out positive and significant, then it would show that the market targets good serial acquirers rather than the bad ones.

Insignificant results would suggest that the market does not consider the total abnormal returns by firms who are serial acquirers when they are targeted, but may use other yardsticks of measurement to decide which group they would like to acquire. If size, a control variable, has a negative and significant coefficient, it would suggest that smaller firms are more likely to become targets and the larger firms are less likely to be targeted. This also applies to the other control variable, debt-to-asset ratio, return on equity and the average target size.

To further investigate the effect of value reducing acquisitions on the probability of a bad serial acquirer becoming either a hostile or a friendly takeover target, the following assumptions are made:

- The logistic transformation of the probability that a firm is a hostile or friendly target for the sample of targets and non-targets; where the dependent variable is set to 1 if the firm becomes a target and 0 if otherwise.

- the logistic transformation of the probability that a firm is a hostile target, for the sample of hostile targets and non-targets; where the dependent variable is set to 1 if the firm becomes a hostile target and 0 if otherwise;

- the logistic transformation of the probability that a firm is a friendly target, for the sample of friendly targets and non-targets; where the dependent variable is set to 1 if the firm becomes the subject of a friendly acquisition and 0 if otherwise 
The logit model in its simple form is expressed as:

$\ln \left(\frac{\pi}{1-\pi}\right)=\log ($ odds $)=$ logit $=\alpha+\beta_{x}$

Hence: $\pi=$ probability $(\mathrm{Y}=$ outcome of interest $/ \mathrm{X}=\mathrm{x})=\left(\frac{e^{a+\beta x}}{1+e^{\alpha+\beta x}}\right)$

Therefore, we constructed the logit regression based on four event windows and with six independent variables as follows:

$\ln \left(\frac{\pi}{1-\pi}\right)=\beta_{0}+\log M V+\beta_{2} . B B D+\beta_{3} A T S+\beta_{4} R O E+\beta_{5} D A R+\beta_{6} C A R *+\varepsilon \ldots \ldots . .3$

Where:

$\log \mathrm{MV}=\log$ of Market Value of the serial Acquirer

$\mathrm{BBD}=\mathrm{Bad}$ bidder dummy $=1$ if the Cumulative Abnormal Returns is negative and 0 if otherwise

ATS $=$ Average Target size $=$ Average target size of that each serial acquirer has bought over the sample period

$\mathrm{ROE}=$ Return on Equity

$\mathrm{DAR}=$ Debt to asset ratio

CAR $* *=$ Cumulative abnormal returns $(* *$ denotes the respective event window)

$\varepsilon=$ Error term

\section{Hypothesis One}

Although the fate of companies that destroy value through bad acquisitions have been tested in the past, most of the current literature has focused on the market effects of announcement 
on stock, caused by investor reactions to merger announcements rather than the motive for takeover. Most of these studies have concentrated in the US. Therefore, our hypotheses examine if these mergers occur to correct past value destroying mergers. Our first null hypothesis states thus:

Ho: Serial Acquirers that make value destroying acquisitions are less likely to become takeover targets

Rejection of the null hypothesis would indicate that investors use takeovers as a tool for corporate punishment and as a preferred form of punishment just as they use other disciplinary tools to discipline value-destroying managers.

\section{Hypothesis Two}

$\mathbf{H}_{0}$ : the mechanism for corporate control (takeovers) functions efficiently in all three defined geographical regions (i.e. US, Europe and the rest of the world)

The rejection of the null hypothesis would be an indication that bad serial acquirers are treated in different ways in the three geographical locations, and would suggest further investigation into the causes of these differences.

\section{Results}

\section{Univariate Analysis}

We examined the relationship between acquisitions and bidder quality, determining if bad bidders are more likely to be acquired than good bidders. Table 4(a) shows the mean and media of the CARs, and the percentage of good and bad bidders in the different geographical regions as well as the whole sample. While the bad bidders are typically in the range between $37 \%$ - 40\%, the good bidders constitute a minimum of $59 \%$ of the sample over all the permutations across the geographical regions and event windows. 
Table 4 (a): Univariate statistics of the percent returns to bidders

The table shows the results of the Univariate statistics of the returns to the bidders in the sample; indicating the proportion of bad and good bidders. The table is split into four panels consisting of the each geographical region.

\begin{tabular}{|c|c|c|c|c|}
\hline \multicolumn{5}{|c|}{ UNIVARIATE STATISTICS: PERCENT RETURNS TO BIDDERS } \\
\hline PANEL A: ALL & {$[-2,2]$} & {$[0]$} & {$[-5,5]$} & {$[-10,5]$} \\
\hline Mean CAR & $6 \%$ & $2 \%$ & $2 \%$ & $4 \%$ \\
\hline Median & $4 \%$ & $1 \%$ & $1 \%$ & $2 \%$ \\
\hline Standard Deviation & $27 \%$ & $11 \%$ & $81 \%$ & $78 \%$ \\
\hline Observations & 2,933 & 2,933 & 2,933 & 2,933 \\
\hline Bad Bidders & 1,084 & 1,098 & 1,198 & 1,173 \\
\hline Good Bidders & 1,849 & 1,835 & 1,735 & 1,760 \\
\hline Percentage Bad & $37 \%$ & $37 \%$ & $41 \%$ & $40 \%$ \\
\hline Percentage Good & $63 \%$ & $63 \%$ & $59 \%$ & $60 \%$ \\
\hline PANEL B: USA & {$[-2,2]$} & {$[0]$} & {$[-5,5]$} & {$[-10,5]$} \\
\hline Mean CAR & $4 \%$ & $2 \%$ & $3 \%$ & $3 \%$ \\
\hline Median & $3 \%$ & $1 \%$ & $1 \%$ & $0 \%$ \\
\hline Standard Deviation & $24 \%$ & $12 \%$ & $26 \%$ & $32 \%$ \\
\hline Observations & 1,274 & 1,274 & 1,274 & 1,274 \\
\hline Bad Bidders & 517 & 535 & 517 & 545 \\
\hline Good Bidders & 757 & 739 & 757 & 729 \\
\hline Percentage Bad & $41 \%$ & $42 \%$ & $41 \%$ & $43 \%$ \\
\hline Percentage Good & $59 \%$ & $58 \%$ & $59 \%$ & $57 \%$ \\
\hline PANEL C: & {$[-2,2]$} & {$[0]$} & {$[-5,5]$} & {$[-10,5]$} \\
\hline Mean CAR & $7 \%$ & $3 \%$ & $-6 \%$ & $3 \%$ \\
\hline Median & $5 \%$ & $1 \%$ & $0 \%$ & $0 \%$ \\
\hline Standard Deviation & $18 \%$ & $9 \%$ & $130 \%$ & $23 \%$ \\
\hline Observations & 838 & 838 & 838 & 838 \\
\hline Bad Bidders & 266 & 233 & 361 & 302 \\
\hline Good Bidders & 572 & 605 & 477 & 536 \\
\hline Percentage Bad & $32 \%$ & $28 \%$ & $43 \%$ & $36 \%$ \\
\hline Percentage Good & $68 \%$ & $72 \%$ & $57 \%$ & $64 \%$ \\
\hline PANEL D: ROW & {$[-2,2]$} & [0] & {$[-5,5]$} & {$[-10,5]$} \\
\hline Mean CAR & $8 \%$ & $3 \%$ & $8 \%$ & $6 \%$ \\
\hline Median & $4 \%$ & $1 \%$ & $5 \%$ & $5 \%$ \\
\hline Standard Deviation & $36 \%$ & $13 \%$ & $71 \%$ & $139 \%$ \\
\hline Observations & 821 & 821 & 821 & 821 \\
\hline Bad Bidders & 301 & 330 & 320 & 326 \\
\hline Good Bidders & 520 & 491 & 501 & 495 \\
\hline Percentage Bad & $37 \%$ & $40 \%$ & $39 \%$ & $40 \%$ \\
\hline Percentage Good & $63 \%$ & $60 \%$ & $61 \%$ & $60 \%$ \\
\hline
\end{tabular}


Table 4(b) shows the result of the frequency with which a bidder is targeted for acquisition. For the entire sample, $8.58 \%$ of the bad bidders are targeted as against $7.19 \%$ of the good bidders, implying that $1.39 \%$ more bad bidders (over good bidders) are targeted. Using the other three windows, the difference is $2.24 \%\{0\}, 010 \%\{-5,5\}$ and $0.80 \%\{-10,5\}$. On the whole, the results suggest that both bad serial acquirers and good serial acquirers are treated almost in the same way. The bad acquirers do not seem more likely to be acquired than their good counterparts.

The composition of the shareholding of these firms also prevents easy takeovers by targets. Large blocks of shares are usually owned by wealthy individuals and/or families who would not give up control simply because the firm is said to be making a value reducing acquisition. They would rather opt to replace a manager they are not pleased with than give up control of their firm.

Finally, when acquisition is the main nucleus of a firm's growth plan and strategy, negative returns around the event would not predispose the shareholders to punish managers especially when they know that the managers of the firm would make adequate returns in the long run which would adequately compensate for the immediate loss that they have experienced.

Table 4 (b) : Univariate results of the frequency with which a bidder is targeted for an acquisition

\section{PANEL A:}

ALL FIRMS

$8 \%$

$(0)$

$(-5,5)$

$(-10,5)$

ALL FIRMS

PANEL B:

\begin{tabular}{lllll} 
BAD BIDDERS & $8.58 \%$ & $9.11 \%$ & $7.76 \%$ & $8.18 \%$ \\
GOOD BIDDERS & $7.19 \%$ & $6.87 \%$ & $7.67 \%$ & $7.39 \%$ \\
DIFFERENCE & $1.39 \%$ & $2.24 \%$ & $0.10 \%$ & $0.80 \%$ \\
\hline
\end{tabular}

This summary of the results from the tables above indicates that the market for corporate control rarely uses takeover as a disciplinary tool on serial acquirers, whether good or bad, 
and would rather use other disciplinary measures to enact control on the managers. The alternate explanation would be that the market expects that subsequent acquisitions by the company would cancel out the negative returns that they have and thus would see no need to discipline the managers now.

\section{Regression results}

\section{Results for Hypothesis One}

The results for hypothesis one are presented in Tables 5-7. The CARs, which is the main variable of interest shows a consistent result across three event windows $\{-2,2\},\{0\}$ and $\{-10,5\}$, where it is both negative and significant at the $10 \%$ level, with coefficients of -0.45 , -1.03 and -0.20 respectively. Although this is in direct contrast to what the Univariate analysis showed, it conforms to what was expected as the norm. It shows that serial acquirers who have a negative total abnormal return are more likely to be targeted than serial acquirers who have positive cumulative abnormal returns. 
Table 5: Logistic regression results for the probability that a firm becomes a subsequent target

The table shows the logistic regression results over several events windows where the dependent variable has been set to 1 if the firm subsequently became a target and 0 otherwise. CAR is the sum of the individual AR from the acquisitions that a firm makes over 10 years observation period.

\begin{tabular}{|ccccc|}
\hline All Firms - Dependent Variable $=1$ if Serial Acquirer became a target, 0 otherwise \\
\cline { 2 - 5 } & \multicolumn{4}{c|}{ EVENT WINDOW } \\
\cline { 2 - 5 } Log_MV & $-2,2\}$ & $\{0\}$ & $\{-5,5\}$ & $\{-10,5\}$ \\
& $-0.06^{* * *}$ & $-0.06^{* * * *}$ & $-0.06^{* * *}$ & $-0.06^{* * * *}$ \\
BBD & $(0.007)$ & $(0.006)$ & $(0.008)$ & $(0.009)$ \\
& 0.07 & 0.13 & 0.21 & 0.15 \\
ATS & $(0.675)$ & $(0.391)$ & $(0.135)$ & $(0.312)$ \\
& $-0.00^{* *}$ & $-0.00^{* *}$ & $-0.00^{* *}$ & $-0.00^{* *}$ \\
ROE & $(0.022)$ & $(0.020)$ & $(0.022)$ & $(0.022)$ \\
& -0.00 & -0.00 & -0.00 & -0.00 \\
DAR & $(0.355)$ & $(0.420)$ & $(0.429)$ & $(0.645)$ \\
& $-0.42^{*}$ & $-0.41^{*}$ & $-0.43^{*}$ & $-0.42^{*}$ \\
CAR & $(0.056)$ & $(0.060)$ & $(0.053)$ & $(0.057)$ \\
& $-0.45^{*}$ & $-1.03^{*}$ & 0.01 & $-0.20^{*}$ \\
Constant & $(0.098)$ & $(0.078)$ & $(0.821)$ & $(0.069)$ \\
& $-1.96^{* * *}$ & $-1.97^{* * *}$ & $-2.05^{* * *}$ & $-2.02^{* * *}$ \\
& $(0.000)$ & $(0.000)$ & $(0.000)$ & $(0.000)$ \\
Observations & 2,879 & 2,879 & 2,879 & 2,879 \\
Model Chi-Square & 25.15 & 25.19 & 22.36 & 27.97 \\
\hline
\end{tabular}

Notes: $\mathrm{p}$ values are in parentheses; *significant at $10 \%$; **significant at $5 \%$; $* * *$ significant at $1 \%$

The fourth event window had a positive coefficient of 0.01 but was not significant. It can thus be inferred that in general, the mechanism for corporate control does function as it is expected: to discipline managers of firms that are serial acquirers which make value reducing acquisitions.

The first explanatory variable, Log_MV, shows a negative coefficient of -0.06 in all four event windows and all are significant at a $1 \%$ level. This suggests that size plays an important role in determining the probability that a firm becomes a target. The implication is that larger firms that make value destroying acquisitions are less likely to be targeted than smaller firms in similar position. 
The average size of the targets (ATS) is also consistently significant at 5\% level across the four estimation windows. This showed that firms that carried out larger deal sizes are less likely to be taken over than firms that carried out smaller deal sizes. These results imply that large companies which are expected to execute large deals are less likely to become target than smaller companies that execute smaller deals. This is in conformity with the findings of Choi et al, (2001).

Finally, the two variables which represent the financial performance of the firm, both show varied results. The effect of ROE is insignificant across the four event windows, suggesting that the financial profitability of a serial acquirer does not affect the probability that it would be a target. This would imply that the shareholders were mainly concerned about the value that is created or destroyed during acquisitions as the major source of gains in the company.

On the other hand, the level of gearing (DAR) is between -0.41 to -0.43 across the four windows and significant at $10 \%$ in all four, suggesting that serial acquirers with a high leverage ratio are less likely to become targets than serial acquirers with a more proportionate level of gearing. This shows that bidders are not too keen on taking on a company with such a high level of risk even though it had the ability to provide a higher tax shield for its new owner. It would also suggest that prospective bidders would require very high returns from such a company (in line with a typical market model portfolio) which they might not be able to offer, given the constant acquisition habit. 
Table 6: Logistic regression results for the probability that a firm becomes a hostile target

The table shows the logistic regression results over several events windows where the dependent variable has been set to 1 if the firm subsequently became a target and 0 otherwise. CAR is the sum of the individual AR from the acquisitions that a firm makes over 10 years observation period.

\begin{tabular}{|ccccc|}
\hline \multicolumn{5}{|c|}{ All Firms - Dependent Variable $=1$ if Serial Acquirer became a hostile target, 0 if a non-target } \\
\cline { 2 - 5 } & $\{-2,2\}$ & $\{0\}$ & $\{-5,5\}$ & $\{-10,5\}$ \\
\hline \multirow{4}{*}{ Log_MV } & 0.06 & 0.05 & 0.06 & 0.05 \\
BBD & $(0.578)$ & $(0.646)$ & $(0.579)$ & $(0.627)$ \\
& 0.03 & -0.22 & -0.04 & -0.10 \\
ATS & $(0.973)$ & $(0.802)$ & $(0.966)$ & $(0.909)$ \\
& -0.00 & -0.00 & -0.00 & -0.00 \\
ROE & $(0.242)$ & $(0.241)$ & $(0.242)$ & $(0.243)$ \\
& -0.00 & -0.00 & -0.00 & -0.00 \\
DAR & $(0.160)$ & $(0.129)$ & $(0.137)$ & $(0.115)$ \\
& 0.01 & 0.02 & 0.01 & 0.01 \\
CAR & $(0.705)$ & $(0.571)$ & $(0.642)$ & $(0.713)$ \\
& $0.39 *$ & -1.50 & $0.14 * *$ & -0.01 \\
Constant & $(0.067)$ & $(0.146)$ & $(0.013)$ & $(0.948)$ \\
& $-6.23 * * *$ & $-6.02 * * *$ & $-6.18^{* * *}$ & $-6.10 * * *$ \\
& $(0.000)$ & $(0.000)$ & $(0.000)$ & $(0.000)$ \\
Observations & 2,694 & 2,694 & 2,694 & 2,694 \\
Model Chi-Square & 12.26 & 11.87 & 22.86 & 11.29 \\
\hline
\end{tabular}

Notes: $\mathrm{p}$ values are in parentheses; $*$ significant at $10 \% ; * *$ significant at $5 \%$; ***significant at $1 \%$

In summary, the results for the estimation of the logit model, presented in Table 5, remain robust after controlling for firm size, leverage, profitability and target size. The results confirm that firms that make good acquisitions are less likely to be targeted than firms that make bad acquisitions.

The results in Table 6 seek to explain the factors that predict the probability that a firm would be a hostile target. Here, apart from the CAR, none of the explanatory variables are statistically significant to predict the probability that a serial acquirer would become a hostile target. When estimated using the 5 day event window, CAR has coefficients of 0.39 and 0.14 which are statistically significant at the $10 \%$ and $5 \%$ levels respectively. 
These results suggest that firms with positive total abnormal returns are more likely to become hostile targets than firms with negative total returns. This would suggest that firms are acquired by others when they feel threatened by their acquisitive habit and are taken over to prevent them from going after some other firms.

Finally, the third sets of results, shown in Table 7, determine the effect of the factors that determine if a firm would become a friendly target. Again, Log_MV shows the same coefficient of -0.04 across all the windows, which are all significant at the $10 \%$ level, indicating that larger firms are less likely to become friendly targets while smaller firms are more likely to be friendly targets. The effect of ATS is also significant across the four windows at $5 \%$ level, indicating that the average size that the serial acquirer had bought in the past could affect the likelihood that it would become a friendly target. 
Table 7: Logistic regression results for the probability that a firm becomes a friendly target

The table shows the logistic regression results over several events windows where the dependent variable has been set to 1 if the firm subsequently became a target and 0 otherwise. CAR is the sum of the individual AR from the acquisitions that a firm makes over 10 years observation period.

\begin{tabular}{|ccccc|}
\hline All Firms - Dependent Variable $=1$ if Serial Acquirer became a friendly target, 0 if a non- \\
target
\end{tabular}

Notes: $\mathrm{p}$ values are in parentheses; *significant at $10 \%$; **significant at 5\%; ***significant at $1 \%$

Interestingly, the leverage (DAR) is only significant when the 11day window is used implying that high leverage makes it less likely to become a friendly target. This is however not significant at the other event windows.

The results indicate that serial acquirers that make value reducing acquisitions are more likely to become targets than those that make value creating acquisitions. The results further show that larger firms are less likely to become targets, but when they do, they are more likely to become hostile targets rather than friendly targets.

There is thus strong evidence to reject the null hypothesis that serial acquirers which make value destroying acquisitions are more likely to become takeover targets. 


\section{Results for Hypothesis Two}

The results for hypothesis two are presented in Tables 8-10. These determine whether the mechanism for corporate control is similar in all the geographical regions of the world; classified as United States (US), Europe (EUR) and the Rest of the World (ROW). Four event windows are used to ensure that the results obtained remain robust and the same variables used on the whole sample.

Table 8 shows the result for the probability that a bad bidder in the US will become a target. The result shows that the cumulative abnormal return (CAR) is the major determinant of whether a serial acquirer subsequently becomes a target in the United States. The negative coefficient of $-0.41,-0.97,-0.51$ and -0.46 , all significant at $10 \%$ level, across the four event windows respectively, indicate that firms that have a negative total abnormal returns are more likely to become targets than firms that have a positive total abnormal return.

The significance of CAR also indicates that firms that purchase smaller firms are more likely to become targets themselves as opposed to firms that make bigger acquisitions who are less likely to become targets. This is indicated by the -0.00 coefficient across the four event windows, all significant at 5\% level. In contrast, the effect of Log_MV is insignificant, which suggests that both large and small firms are equally likely to become targets subject to their acquisition performance and the size of the targets they had previously purchased. 
Table 8: Logistic regression results for the probability that a bad bidder becomes in the US becomes a target

The table shows the logistic regression results over several events windows where the dependent variable has been set to 1 if the firm subsequently became a target and 0 otherwise. CAR is the sum of the individual AR from the acquisitions that a firm makes over 10 years observation period. Firms are indigenous to the United States.

\begin{tabular}{|c|c|c|c|c|}
\hline \multicolumn{5}{|c|}{ Dependent Variable $=1$ if Serial Acquirer became a target, 0 otherwise } \\
\hline & \multicolumn{3}{|c|}{ EVENT WINDOW } & \multirow[b]{2}{*}{$-10,5$} \\
\hline & $\{-2,2\}$ & $\{0\}$ & $\{-5,5\}$ & \\
\hline \multirow[t]{2}{*}{ Log_MV } & -0.03 & -0.03 & -0.03 & -0.03 \\
\hline & $(0.478)$ & $(0.480)$ & $(0.497)$ & $(0.489)$ \\
\hline \multirow[t]{2}{*}{ BBD } & 0.09 & 0.14 & 0.11 & 0.11 \\
\hline & $(0.680)$ & $(0.426)$ & $(0.561)$ & $(0.547)$ \\
\hline \multirow[t]{2}{*}{ ATS } & $-0.00 * *$ & $-0.00 * *$ & $-0.00 * *$ & $-0.00 * *$ \\
\hline & $(0.036)$ & $(0.032)$ & $(0.036)$ & $(0.038)$ \\
\hline \multirow[t]{2}{*}{ ROE } & -0.00 & -0.00 & -0.00 & -0.00 \\
\hline & $(0.909)$ & $(0.996)$ & $(0.997)$ & $(0.988)$ \\
\hline \multirow[t]{2}{*}{ DAR } & -0.30 & -0.29 & -0.31 & -0.32 \\
\hline & $(0.156)$ & $(0.170)$ & $(0.142)$ & $(0.131)$ \\
\hline \multirow[t]{2}{*}{ CAR } & $-0.41^{*}$ & $-0.97 *$ & $-0.51^{*}$ & -0.46 \\
\hline & $(0.070)$ & $(0.088)$ & $(0.057)$ & $(0.130)$ \\
\hline \multirow[t]{2}{*}{ Constant } & $-1.54 * * *$ & $-1.56 * * *$ & $-1.56 * * *$ & $-1.56 * * *$ \\
\hline & $(0.000)$ & $(0.000)$ & $(0.000)$ & $(0.000)$ \\
\hline Observations & 1,267 & 1,267 & 1,267 & 1,267 \\
\hline Model Chi-Square & 12.02 & 12.31 & 13.78 & 13.73 \\
\hline
\end{tabular}

Notes: $\mathrm{p}$ values are in parentheses; ${ }^{*}$ significant at $10 \% ; * *$ significant at $5 \%$; ***significant at $1 \%$

The evidence for the United States seems characteristic of a mature economy where the stock market is deep and investors usually have no personal interests in the companies that they invest in except for the expectation of returns from their investments.

Table 9 shows the results of the European sample. Similar to the US, CAR is the major factor that influences the probability that a firm would subsequently become a target. Of the four coefficients obtained for CAR from the four event windows, two are positive but insignificant (0.17 and 0.03$)$ for the 5-day and 11-day event windows respectively while the other two are 
negative and significant at the $10 \%$ level, $(-2.69$ and -1.17) for the event day and the 16-day window.

Table 9: Logistic regression results for the probability that a bad bidder becomes in the Europe becomes a target

The table shows the logistic regression results over several events windows where the dependent variable has been set to 1 if the firm subsequently became a target and 0 otherwise. CAR is the sum of the individual AR from the acquisitions that a firm makes over 10 years observation period. Firms are indigenous to the Europe.

\begin{tabular}{ccccc}
\hline \multicolumn{5}{c}{ Dependent Variable $=1$ if Serial Acquirer became a target, 0 otherwise } \\
& $\{-2,2\}$ & EVENT WINDOW & $\{-10,5\}$ \\
Log_MV & -0.02 & -0.03 & -0.02 & -0.02 \\
& $(0.851)$ & $(0.782)$ & $(0.844)$ & $(0.855)$ \\
BBD & 0.12 & -0.08 & 0.09 & -0.13 \\
& $(0.841)$ & $(0.879)$ & $(0.867)$ & $(0.823)$ \\
ATS & -0.00 & -0.00 & -0.00 & -0.00 \\
& $(0.360)$ & $(0.360)$ & $(0.359)$ & $(0.357)$ \\
ROE & 0.01 & 0.01 & 0.01 & 0.01 \\
& $(0.331)$ & $(0.350)$ & $(0.341)$ & $(0.428)$ \\
DAR & -1.08 & -1.11 & -1.06 & -1.03 \\
& $(0.138)$ & $(0.129)$ & $(0.141)$ & $(0.147)$ \\
CAR & 0.17 & $-2.69 *$ & 0.03 & $-1.17 *$ \\
& $(0.878)$ & $(0.077)$ & $(0.605)$ & $(0.076)$ \\
Constant & $-3.61 * * *$ & $-3.43 * * *$ & $-3.59 * * *$ & $-3.51 * * *$ \\
& $(0.000)$ & $(0.000)$ & $(0.000)$ & $(0.000)$ \\
& & & & 825 \\
Observations & 825 & 825 & 825 & 5.83 \\
Model Chi-Square & 4.56 & 5.44 & 4.45 & \\
& & & & \\
\end{tabular}

Notes: $\mathrm{p}$ values are in parentheses; $*$ significant at $10 \% ; * *$ significant at $5 \%$; ***significant at $1 \%$

The results for Europe indicates that firms that make negative cumulative abnormal returns are more likely to expose themselves as the subjects of acquisition than those that have positive abnormal returns.

Finally, Table 10 is the result from the last geographical group, ROW (Rest of the World). In sharp contrast to the other two groups, the most influential variable is Log_MV, which has a 
significant coefficient of -0.22 across the four event windows. This indicates that the larger the firm, the less likely it would subsequently become a target.

Table 10: Logistic regression results for the probability that a bad bidder becomes in the Rest of the World becomes a target

The table shows the logistic regression results over several events windows where the dependent variable has been set to 1 if the firm subsequently became a target and 0 otherwise. CAR is the sum of the individual AR from the acquisitions that a firm makes over 10 years observation period. Firms are indigenous to all countries except those in Europe and United States.

\begin{tabular}{|c|c|c|c|c|}
\hline \multicolumn{5}{|c|}{ Dependent Variable $=1$ if Serial Acquirer became a target, 0 otherwise } \\
\hline & \multicolumn{3}{|c|}{ EVENT WINDOW } & \multirow[b]{2}{*}{$-10,5$} \\
\hline & $\{-2,2\}$ & $\{0\}$ & $\{-5,5\}$ & \\
\hline \multirow[t]{2}{*}{ Log_MV } & $-0.22 * * *$ & $-0.21 * * *$ & $-0.21 * * *$ & $-0.21 * * *$ \\
\hline & $(0.000)$ & $(0.000)$ & $(0.000)$ & $(0.000)$ \\
\hline \multirow[t]{2}{*}{ BBD } & -0.50 & -0.43 & -0.35 & -0.48 \\
\hline & $(0.203)$ & $(0.291)$ & $(0.326)$ & $(0.198)$ \\
\hline \multirow[t]{2}{*}{ ATS } & -0.00 & -0.00 & -0.00 & -0.00 \\
\hline & $(0.531)$ & $(0.522)$ & $(0.529)$ & $(0.524)$ \\
\hline \multirow[t]{2}{*}{ ROE } & -0.00 & -0.00 & -0.00 & $-0.00 * * *$ \\
\hline & $(0.367)$ & $(0.378)$ & $(0.358)$ & $(0.003)$ \\
\hline \multirow[t]{2}{*}{ DAR } & 0.50 & 0.52 & 0.51 & 0.56 \\
\hline & $(0.292)$ & $(0.272)$ & $(0.290)$ & $(0.249)$ \\
\hline \multirow[t]{2}{*}{ CAR } & -0.41 & -0.69 & -0.00 & $-0.17 * * *$ \\
\hline & $(0.472)$ & $(0.517)$ & $(0.966)$ & $(0.001)$ \\
\hline \multirow[t]{2}{*}{ Constant } & $-1.29 * * *$ & $-1.34 * * *$ & $-1.41 * * *$ & $-1.36 * * *$ \\
\hline & $(0.001)$ & $(0.001)$ & $(0.000)$ & $(0.000)$ \\
\hline Observations & 790 & 790 & 790 & 790 \\
\hline Model Chi-Square & 19.98 & 20.18 & 20.15 & 54.52 \\
\hline
\end{tabular}

Notes: $\mathrm{p}$ values are in parentheses; *significant at $10 \%$; **significant at 5\%; ***significant at $1 \%$

Only one of the CAR coefficients is significant which suggests that the total abnormal return is not a major consideration in the likelihood of a firm becoming a target for the rest of the world. This is in line with the Univariate analysis and with the current cultures where wealthy individuals and families own large conglomerates and do not give up control because the firm 
made poor acquisitions. Instead, they would rather sack the managers responsible since they can easily do this as they have majority control of the firms.

Based on the results obtained, we reject the null hypothesis and conclude that serial acquirers are treated in the same way in all three regions.

\section{Conclusion}

The study tests the hypothesis that bad serial acquirers are more likely to become target themselves compared to good serial acquirers. We find that the probability that a bad bidder would become a target is higher than that of a good bidder. This is consistent with previous studies (Mitchell and Lehn, 1990; and Choi et al, 2001) on takeovers as a measure of discipline and corporate governance mechanism which established that bad bidders are more likely to be subsequent targets. We extend this hypothesis to firms operating in other continents and establish a similar pattern of disciplinary measures against managements that are bad serial bidders.

Our result on the Rest of the World (ROW), which comprising mostly the developing countries in Africa and Asia, establish that bad bidders are less likely to be acquired than other serial acquirers who have been considered to have better returns over their acquisitions. This implies that there is limitation in the application of the positivist agency theory across countries and catalysed by the cultural difference and huge economic disparity among developing and developed countries. 


\section{References}

Baker, G.P. and Kennedy, R.E. (2002) Survivorship and the Economic Grim Reaper. Journal of Law, Economics, and Organization, 18 (2): 324-361

Chemla, G. (2005) Hold-up, stakeholders and takeover threats. Journal of Financial Intermediation 14, 376-397

Choi, Y.K., Franks, J., Mayer, C. and Renneboog, L. ( 2001) The choice of organizational form: The case of post-merger managerial incentive structure. Journal of Financial Management 22 ( 4), 69-82

Denis, D.J. and Kruse, T.A. (2000) Managerial discipline and corporate restructuring following performance declines. Journal of Financial Economics 55, 391-424

Eisenhardt, K.M. (1989) Agency theory: an assessment and review. The Academy of Management Review 14(1), 63-74.

Frank, J. and Mayer, C. (1996) Hostile takeovers and the correction of managerial failure. Journal of Financial Economics 40, 163.-181

Franks, J. and Mayer, C (1996) Hostile takeovers and the correction of managerial failure. Journal of Financial Economics, 40 ( 1), 163-181.

Franks, J., Mayer, C. and Renneboog, L. (2001) Who disciplines management in poorly performing companies? Journal of Financial Economics 40 (1), 163-181

Gorton, G., Kahl, M., Rosen, R., (2009), Eat or Be Eaten: A Theory of Merger Firm Size. Journal of Finance 64(3), 1291 -1344

Grinstein, Y. (2006) The disciplinary role of debt and equity contracts: Theory and tests. Journal of Financial Intermediation 15, 419-443

Humphery-Jenner, M.L. (2012) Internal and external discipline following securities class actions. Journal of Financial Intermediation 21, 151-179

Jensen, M. C, and Meckling, W. H. (1976) Theory of the Firm: Managerial Behaviour, Agency Costs and Ownership Structure. Financial Economics 3, 305-60.

Kini, O., Kracaw, W., Mian, S. ( 2004), The Nature of Discipline by Corporate Takeovers, Journal of Finance 59(4), 1511-1552.

Lehn, K.M. and Zhao, M. (2006). CEO Turnover after Acquisitions: Are Bad Bidders Fired? 
Journal of Finance, 61 (4), 1759-1811.

Mitchell, M.L. and Lehn, K. (1990) Do bad bidders become good targets? Journal of Political Economy 98(2), 372-398

Mikkelson, W.H. and Partch, M.M.( 1997) The decline of takeovers and disciplinary managerial turnover. Journal of Financial Economics, 44, 205- 228

Offenberg, D. (2009). Firm Size and the Effectiveness of the Market for Corporate Control. Journal of Corporate Finance, 15(1), 66-79

Palepu, K.G (1986) Predicting Takeover Targets. Journal of Accounting \& Economics, 8 (1), 3-35

Scharfstein, D. (1988) The Disciplinary Role of Takeovers. Review of Economic Studies, 55 (18), $185-192$.

Shivdasani, A. (1993) Board composition, ownership structure, and hostile takeovers. Journal of Accounting and Economics 16, 167-198.

Sudarsanam, S. and Mahate, A., (2003) Glamour acquirers, method of payment and postacquisition performance: The UK evidence. Journal of Business Finance and Accounting, 30(1\&2), 299-341.

Weisbach, M.S. (1993) Corporate governance and hostile takeovers. Journal of Accounting and Economics 16, 199-208. 